\title{
Differences in hi-tech immigrant earnings and wages across Canadian cities
}

PETER V. HALL

Urban Studies Program, Simon Fraser University, 515 West Hastings Street, Vancouver, V6B 5K3, British Columbia, Canada (e-mail: pvhall@sfu.ca)

AMIR J. KHAN

Social Policy and Development Centre, 15-Maqbool Co-operative Housing Society, Block 7 \& 8, Karachi 75350, Pakistan (e-mail: amirkhan@spdc.org.pk)

This paper examines the relative earnings and wages of immigrants working in the hi-tech sector in Canada's cities. Between 1990 and 2000, a sizeable earnings advantage of immigrants over nonimmigrants employed in the hi-tech sector evaporated, and this change was most noticeable in the largest cities. We use population census microdata to examine the geographical dimensions of this shift. After controlling for individual characteristics, we show that immigrants in the largest and tech-intensive cities earn significantly less relative to nonimmigrants than those in midsized and smaller cities. We also present results comparing the hi-tech immigrant wage and earnings gap for the five largest Canadian cities. The findings are consistent with the notion that geographic differences are an important component of the overall earnings gap between immigrants and nonimmigrants.

Key words: immigrants, earnings, wages, urban, hi-tech, difference-in-differences
Les différences entre les gains et salaires des immigrants du secteur des hautes technologies dans les villes canadiennes

Cet article aborde la question des gains et salaires relatifs des immigrants qui se sont établis dans les villes canadiennes et qui travaillent dans le secteur des hautes technologies. De 1990 à 2000, nous assistons à la disparition d'une partie considérable de l'avantage des gains d'emploi dans le secteur des hautes technologies entre les immigrants et les non immigrants. Ce changement s'est produit davantage dans les grandes villes. Notre analyse des dimensions géographiques de ce glissement repose sur les microdonnées du recensement de la population. En contrôlant pour les caractéristiques individuelles, il ressort que les immigrants des grandes villes les plus avancées sur le plan technologique gagnent beaucoup moins que les non immigrants, comparativement à ceux des villes moyennes et petites. Nous présentons également des résultats comparant les écarts de gains et salaires des immigrants travaillant dans le secteur des hautes technologies dans les cina plus grandes villes canadiennes. Les conclusions que nous tirons sur l'évolution du marché du travail rejoignent l'idée selon laquelle les différences sur le plan 


\section{Introduction}

It is well known that immigrants to Canada tend to settle in locations at the very top of the urban hierarchy, that is, in the three largest metropolitan areas (Hiebert 2000). Hi-tech economic activity, which is important for overall national economic growth, also tends to cluster geographically to take advantage of face-to-face contacts and other highly localized sources of global competitive advantage (Wolfe 2003). Often, but not always, these clusters of hi-tech activity are also found at or near the top of the urban hierarchy (Coffey and Shearmur 1997; Shearmur and Doloreux 2007). The selective geography of immigrant settlement and hi-tech clustering thus raise important questions for public policy related to the distribution of opportunity and activity across the Canadian urban system. A central concern raised by these selective patterns of immigration and hi-tech development is that they may be reinforcing global and national trends for the largest cities to outgrow smaller places (Bourne and Simmons 2003).

This paper focuses on a second set of closely related concerns. Not only are immigration and hi-tech development spatial selective, we have also come to understand that they are socially selective processes. Many researchers, policy makers and advocates have raised concerns about the matching of highly skilled immigrants to appropriate employment opportunities and about the prospects for the upward mobility of immigrants in the Canadian labour market (Hum and Simpson 2004; Picot 2004). We also know that the benefits of economic activity in hi-tech clusters are not equally distributed; several authors have noted that many sectors in the emerging knowledge economy are associated with increasingly bifurcated labour markets where increasing returns to skill co-exist with increasing labour market churning and contingency (Benner 2002; Cranford et al. 2003). What happens to géographique constituent un facteur explicatif de l'écart total de gains entre les immigrants et les non immigrants.

Mots clés: immigrants, gains, salaires, urbain, haute technologie, différence des différences

wages and earnings inside those metropolitan areas that receive most immigrants and hi-tech activity? Do we find greater earnings and wage inequality in these cities? How do immigrants fare in comparison to the native-born in these cities?

In this paper we argue that where the two spatially and socially selective trends-immigration and hi-tech clustering-coincide, the potential exists for systematic exclusion and labour market segmentation. Indeed, Warman and Worswick (2004) have shown that the earnings difference between immigrants and the native-born in all sectors varies across the eight largest cities in Canada. Their results suggest that immigrants to the largest CMAs 'experience a lower level of immigrant economic integration' (p. 62) than do immigrants to Canada overall. And, because immigrants overwhelmingly favour these large city destinations that have higher than average earnings levels, analysis of the integration of immigrants that ignores geographic differences may underestimate the gap between immigrant and native-born earnings. However, Warman and Worswick's (2004) suggestive results do not control for differences in education or other individual characteristics nor do they control for differences in economic sector. This paper presents the results of a multivariate analysis of the earnings and wages of immigrants working in the hitech sector in Canada's cities, using confidential microdata from the 1991, 1996 and 2001 population censuses. By using microdata and by focusing on a single category of economic activity, we provide a controlled analysis of the differences in hi-tech immigrant wages and earnings across Canadian cities. We show that there are significant geographical variations in the earnings of immigrants relative to those of the native-born in the hi-tech sector.

The paper begins with a review of literature on immigrants, local labour market outcomes and hi-tech clustering. Our review suggests that immigrants are likely to experience lower relative

The Canadian Geographer / Le Géographe canadien 52, no 3 (2008) 
earnings in those local labour markets where many immigrants are already present, but that this general tendency is contingent on a variety of place-specific circumstances. We then present the empirical material in four sections. First, we note the evaporation of a raw or unadjusted earnings difference between immigrants and nonimmigrants working in the hi-tech industry between 1990 and 2000, especially in places at or near the top of the urban hierarchy. Second, we present our earnings equation framework and discuss data issues. Our overall results confirm the Canada-wide decline in immigrant relative wages and earnings already noted in the literature. Third, we then show that the earnings and wage differences are greatest in the largest cities, followed by hi-tech intensive midsized cities. Finally, we compare immigrant wages and earnings differences in the five largest cities, noting an important difference between Toronto and other large cities. The findings highlight a central dilemma for Canadian urban development policy, namely, that the largest and most hi-tech intensive cities are also the places where the relative earnings gap for immigrants is greatest.

\section{Immigrants, Hi-Tech Clusters and the Local Labour Market}

What happens when immigrants settle in a local labour market? Much of the recent literature addressing this question comes from work by economists who have studied the effects of immigrants on the labour markets of various United States cities. We need to be cautious in how we interpret these lessons in the Canadian context. A simple supply and demand framework would suggest that an increase in the supply of labour results, other things being equal, in lower wages for both immigrants and natives. However, in his seminal analysis, Card (1990) showed that the sudden influx of large numbers of relatively unskilled Cuban immigrants to Miami as a result of the Mariel boatlift did not have significant impacts on the city's less-skilled residents. This finding has found wide support across several empirical studies in a variety of contexts (see Borjas 1994), and it has become widely accepted that inward migration has relatively little impact on the labour market outcomes of locals.
This is not necessarily the case for immigrants already residing in places that receive additional immigrants.

The precise nature of the mechanism(s) by which absorption of migrants occurs remains unclear. One explanation is that an influx of immigrants leads to local out-migration; another explanation is that an influx of workers with particular skill characteristics will shift the industrial and exporting mix of a local economy towards these skill characteristics. However, in a recent paper re-examining the Mariel boatlift, Lewis (2004) showed that locals did not leave and that industrial mix did not change in Miami following the boatlift; in other words, Miami did not become more specialized as an exporter of low-skill content products and services. Instead, using microdata from an annual survey of manufacturers, Lewis traces a form of intrasector production technology adjustment. In comparison to other cities, industries within Miami became more labour-intensive, and computer use at work was also lower. This intriguing explanation rests on the notion that production technologies may vary from place to place according to local factor endowments and path-dependent trajectories of industrial development. The assertion that there are regional variations in technology adoption enjoys wide support in the economic geography literature, and has previously been noted in studies of the Canadian manufacturing sector (see Rigby and Haydamack 1998; also Rigby and Essletzbichler 2006).

More recent work by labour economists suggests that the arrival of immigrants may actually raise the wages and earnings of nativeborn workers. In a series of articles, Ottaviano and Peri $(2005,2006)$ have developed the argument that immigrants, even when they have similar education and skills as the native-born, are complements rather than substitutes for nativeborn workers. This turns out to be a very powerful explanation for why immigrants do not suppress the wages of the native-born; immigrants have both cultural and technical knowledge that the native-born do not have. Hence instead of competing with the native-born for jobs (substitutes), they may allow the nativeborn to be more productive (complements). Likewise, in an earlier Canadian study, Laryea (1998) found that foreign-born labour had an overall 
complementary effect on the wages of Canadianborn workers, although in some sectors (excluding hi-tech), foreign-born workers may have displaced locals.

There are, however, two important caveats to the research that argues that immigrant's skills generally complement those of the native-born. First, immigrants may compete with native-born workers with low education levels, such as those with less than a high school completion. This empirical finding has important policy consequences, but it is unlikely to explain dynamics in the hi-tech industry; the second caveat is directly relevant to the current study. While immigrant's skills and knowledge may complement those of the native-born, they 'are most closely substitutes for those held by other immigrants' (Peri 2007,8 , emphasis in original). Hence, immigrants are likely to be in competition with other current and recent immigrants seeking work in the same local labour market. This is another way of saying that immigrant status is one among the many social cleavages that demarcate segmentation in local labour markets (Peck 1996; Martin 2000). A logical implication of this line of argument, one that we examine empirically in this paper, is that immigrants moving to labour markets where many immigrants have previously settled may experience a reduction in their relative earnings. In Canada, the cities with these characteristics are concentrated at the top of the urban hierarchy.

Referring to immigrant's skills as complements or substitutes may seem overly reductionist to some, but one example of how immigrant's skills are complementary in the hi-tech sector is provided in Saxenian's work focusing on high-skilled immigrants in Silicon Valley's technology sectors. Saxenian has shown that immigrants contribute to regional economic growth by fostering international trade and a variety of technological interactions (see Saxenian 1999, 2006). Knowledge about how to produce, customize and sell in foreign markets is one example of the way in which immigrants complement the nativeborn, thus making them more productive. Gertler (2001) has made similar arguments in support of the role that immigrants can play in Canada.

This way of thinking about the place of immigrants in local labour markets does not deny that immigrants often face considerable barriers to mobility, nor does it suggest that barriers exist only for those in relatively low-skill positions. Indeed, Saxenian (1999) notes that Chinese and Indian-born immigrants in Silicon Valley faced considerable barriers to upward occupational mobility. However, for some very particular reasons, some of these immigrants were able to respond to these barriers by engaging in hi-tech entrepreneurial activities, with the result that on average, these immigrants do not earn less than their native-born counterparts. Tang (1993) and Fernandez (1998) support these findings on earnings and relative occupational mobility. These 'very particular reasons' have a great deal to do with Silicon Valley's particular regional industrial system that supports innovation and firm formation (Saxenian 1994); in other words, place matters.

It is by no means clear that Canadian hi-tech clusters, or indeed for that matter other parts of the economy, offer similar possibilities for mobility through entrepreneurship to first-generation immigrants. Indeed, despite Canada's long record of successfully accepting and accommodating immigrants from a variety of backgrounds, various barriers to the upward mobility of immigrants have recently become apparent (see Reitz 2001; Frennette and Morissette 2003; Hum and Simpson 2004; Picot 2004; Sweetman 2004). For example, using data from the Survey of Labour and Income Dynamics for 1993, Hum and Simpson (1999) showed that immigrants to Canada who are members of visible minority groups receive lower wage offers than do comparable nativeborn workers. The only exception to this rule is native-born black men, who also receive lower wage offers. In one of the few studies comparing labour market dynamics across different Canadian cities, Pendukar and Pendukar (2002) found that the earnings gap between Canadianborn white workers, and visible minority and Aboriginal workers grew between 1991 and 1996.

In academic writing and in public policy discourse, particular concerns have been raised about the lack of recognition of foreign education and certification (see HRSDC 2003; ICP 2003; Alboim et al. 2005), and the discounting of foreign experience of immigrants that are older, visible minorities and non-English speakers (see Schaafsma and Sweetman 2001; Anisef et al. 2003; Avdemir and Skuterud 2005). Bauder 
(2003) argues that nonrecognition of foreign credentials and experience of immigrants by professional associations and employers leads to their active exclusion from the upper segments of the labour market. These arguments have also been applied to the so-called knowledge economy, which overlaps with this paper's definition of the hi-tech sector. Reitz (2005) argues that in order to understand the declining earnings of immigrants relative to nonimmigrants, one needs to take into account the particular importance placed on certification of skills and experience in the knowledge economy. Although this structural shift affects all new labour market entrants, new immigrants face particularly intense barriers to the recognition of previous experience.

In which places are we likely to find a greater divergence between immigrant and native-born earnings? We argue that a proper appreciation of both geographic hierarchy and diversity is an important part of resolving the conflicting views of immigrant labour market absorption, and to understanding the relative position of immigrants in specific places. The notion that the position or rank of a city in the urban hierarchy has an important influence on the fortunes of that place enjoys a long lineage in the field of geography that can be traced back to the work of Christaller (1933), Hall (1966), and Friedmann and Wolff (1982). While the world city or global city hypothesis is typically used to account for differences between cities, Sassen (1991) does make the argument that cities at the very top of the global urban hierarchy are more likely to experience increasing social fragmentation. Sassen's causal mechanism for increasing inequality may be thought of as intersectoral; at the risk of oversimplifying her arguments, labour market dualism arises when immigrants (and other groups of workers confined to particular labour market segments) provide personal services such as house cleaning and restaurant meals to global financial traders. These arguments about overall greater inequality within cities at or near the top of the urban hierarchy are compatible with the perspective developed in this paper.

However, urban hierarchy-based arguments do not directly address the question of intrasectoral inequality within a given place; in other words, they cannot account for the possibility that workers in the same sector in the same place may experience divergent labour market outcomes. Geographers have long asserted that space and place have important implications for labour market outcomes (Peck 1996). This is not the same thing as saying that general principles and extra-local processes are irrelevant, but it is to recognize that these principles and processes 'resolve' differently in particular places. If this view is correct, then we cannot simply read off immigrants outcomes from the standing of a city in the urban hierarchy. Instead, we recognize that immigrants may be situated in local labour markets in a variety of different ways. Not only do labour demand and supply conditions vary considerably across Canada, labour markets are embedded in systems of social regulation that also vary from place to place. Immigrants may fill critical skills shortages, provide linkages to external resources and markets, or engage in entrepreneurial activity. At the same time, the employment of immigrants may allow employers to implement strategies of increased labour market flexibility, and in some places immigrants may find themselves competing with other immigrants in segmented labour markets.

Our review of the literature suggests that we should look for this to occur in places which receive the largest numbers of immigrants. It is in these places where immigrants are more likely to be in competition with each other. However, our literature review has not suggested that immigrants are likely to receive lower relative earnings in all places with significant clusters of hitech activity; this outcome is contingent on a variety of place-specific processes and factors. Hence, in the Canadian context, where immigrant settlement and hi-tech economic development cooccur at or near the top of the urban hierarchy, we should not necessarily expect immigrants to earn relatively less in all of the largest cities. In the empirical analysis that follows, we present evidence of variations in labour market outcomes for immigrants across Canadian cities while controlling for industrial sector and a variety of individual demographic and human capital characteristics. What we find supports the literature; generally immigrants do perform worse relative to the native-born in the largest and most techintensive cities, but there are large-city exceptions to this general rule. 


\section{Earnings Differences between Immigrants and Native-Born in the Hi-Tech Sector}

Employment of immigrants in the hi-tech sector is to a large extent a reflection of overall trends in the Canadian urban space-economy. Immigrants in the hi-tech sector are settling and finding employment in the same highly selective fashion as are all other immigrants; that is, they are most likely to settle in the largest urban centres. The geography of hi-tech immigrant employment thus appears to be closely related to overall hi-tech and overall urban economic growth trends. In coming to this conclusion, we have analyzed customized census tabulations on the employment of immigrants in the hi-tech industry in the 43 largest census metropolitan areas/census agglomerations (CMA/CA) for the period $1991-2001^{1}$.

There are various ways to define the hi-tech sector, each related to different understandings of the fundamental nature of hi-tech activity, the relative importance of patterns of local and extra-local interaction, and the role of information and knowledge in the development process. As a practical matter, however, these definitions often converge when applied to the standard industrial classification schemes (Shearmur and Doloreux 2007). Given our interest in comparing the wages and earnings of two legally defined categories of workers, we wanted a definition for the hi-tech sector that would capture those doing similar work requiring similar skills and education regardless, in some sense, of where they fell in the available economic sector classification schemes. For example, it makes little difference to us whether a software engineer is in aeronautical engineering, management consulting or in the narrowly defined software development sector; we want to include them in our study. The classification issue is problematic in what is by

1 CAs consist of one or more contiguous municipalities with a central urban core with at least 10,000 people in the urban core. A CMA is a CA with an urban core containing at least 100,000 people. We began with a Census Custom Tabulation of the 50 largest CMAs/CAs in Canada, but excluded the seven CAs with 100 or fewer hi-tech immigrants in any census period since 1991. The excluded CAs are: Cape Breton, Chicoutimi-Jonquiere, Drummondville, Medicine Hat, North Bay, Saint-Jean-sur-Richelieu and Trois-Rivieres. definition, a dynamic and changing sector of the economy. For these reasons, we sought a relatively broad definition of the hi-tech sector that included both manufacturing and advanced services. Furthermore, in the paper, we draw a distinction between hi-tech industry, referring to the activities of the firm in which the individual is employed, hi-tech occupations, referring to nature of the work performed by the individual, and the hi-tech sector, which includes both industries and occupations.

Our definition of the hi-tech industry consists of 12 hi-tech industry subsectors that are constructed out of sixteen 3-digit Standard Industrial Classification (SIC-E 1980) industries ${ }^{2}$. We used the scheme for defining the hi-tech industry proposed by Gertler et al. (2002), which includes aircraft, office, electrical, and scientific equipment manufacturing, bio-medical, telecommunications, computer, engineering and scientific services and film. However, following Saxenian (1999), we also added various subsectors to better capture the breadth of hi-tech activity, including communication equipment manufacturing, electrical wholesales, employment agencies and management consulting. We use this definition of the hi-tech industry only to identify the spatial distribution of hi-tech activity and immigrant employment, and in our cluster analysis to identify classes of cities with respect to immigrant hi-tech employment.

For all wages and earnings comparisons and regressions, we use the hi-tech sector definition, which includes both industries and occupations. We included both industries and occupations in our definition of the hi-tech sector in light of recent debates about the nature and classification of hi-tech economic activity. Chapple et al. (2004) argue for an occupation-based definition of hi-tech activity: '(b)y abandoning narrow notions restricted to maturing technologies in computers, electronics, and telecommunications and instead using science and technology (S\&T) occupations as a marker for high-tech, it may be possible to tag the innovative potential of emerging sectors, including high-tech services' (11). Their hi-tech occupation definition includes scientists, engineers, technicians, programmers, analysts,

2 These are SIC-E (1980) codes 321, 335, 336, 374, 868, 391, $482,483,574,579,771,772,775,777,779$ and 961. 
technologists, technology managers and inspectors and line and cable workers. We created a concordance between their US Census-based occupational classification scheme and the Statistics Canada Standard Occupational Classification of 1991 (SOC). Our definition of a hi-tech occupation includes 33 of the 4-character SOC occupations ${ }^{3}$.

Three general observations emerge from our analysis of the aggregate numbers of immigrants employed in the hi-tech industry in larger Canadian cities. First, the five largest cities in terms of population and employment (Toronto, Montréal, Ottawa, Vancouver and Calgary) contain most of the employed immigrants. In 2001, these cities accounted for 40.4 percent of the Canadian population, 41.5 percent of all employment, but 70.8 percent of immigrant employment. The three largest cities, Toronto, Montréal and Vancouver, alone were home to over threefifths of all employed immigrants. This finding confirms numerous previous studies (see Hiebert 2000).

Second, the largest cities in Canada are also centres of hi-tech activity. Depending on which indicator is used, at least 20 cities can be described as having significant concentrations of employment in one or more hi-tech subsector. However, only nine cities have a location quotient of greater than one for the aggregate hi-tech industry class, namely Calgary, Halifax, Moncton, Montréal, Oshawa, Ottawa, Saint John, Toronto and Vancouver. This finding also confirms previous studies that have identified the tendency for hi-tech, producer services and knowledge-intensive industries to locate in clusters at or near the top of the Canadian urban hierarchy (Coffey and Shearmur 1997; Gertler et al. 2002; Shearmur and Doloreux 2007).

Third, immigrants are overrepresented in the hi-tech industry. Over one-quarter (28 percent) of those employed in the hi-tech industry in 2001 were immigrants, although immigrants only accounted for one-fifth (20.3 percent) of all employed in Canada. Immigrants appear to be playing an increasingly important role in the hi-tech

3 These are SOC (1991) codes A121, A122, B022, B521, B522, C011, C012, C013, C015, C021, C033, C041, C046, C047, C062, C063, C111, C121, C132, C133, C141, C143, C144, C161, D211, D212, D215, D218, H211, H212, H214, H215 and H216. economy; the proportion of all hi-tech employment taken by immigrants was up from 24 percent in 1991.

As expected, given the three foregoing observations, immigrants in hi-tech employment are overrepresented in the largest cities. While almost two-thirds (63.7 percent) of hi-tech employment is found in the five largest cities, 83.1 percent of immigrants employed in the hi-tech industry reside there. In summary, the employment of immigrants in the hi-tech industry in Canada is highly concentrated in the main urban centres.

Immigrants in hi-tech employment used to enjoy an earnings advantage over the native-born working in the same sector, but this difference evaporated over the decade of the 1990s. The first row of Table 1 shows that whereas in 1990 (as reported in the 1991 Census) immigrants in hi-tech employment earned an average of $\$ 2,565$ or 7.7 percent more than the nativeborn in hi-tech employment; by 2000 this difference had evaporated. This change in the unadjusted difference in earnings between immigrants and the native-born in hi-tech employment replicates what has been observed in comparisons between immigrants and the native-born in the economy overall.

Geography is also clearly present in this change; during 1990, in 22 of the 43 cities studied, average earnings of immigrants in hi-tech employment were significantly above those of the native-born in hi-tech employment, and in only one city (Toronto) were earnings of immigrants significantly below those of the native-born. By 2000, earnings of hi-tech immigrants were significantly below those of the native-born in eight cities, including four of the five largest cities. The switch was most dramatic in the largest cities. During 1990, Toronto's immigrants employed in the hi-tech sector earned $\$ 2,561$ or 6.7 percent less per year than the native-born; by 2000 , the gap was $\$ 9,772$ or 18.1 percent less per year. In Montréal, Vancouver and Calgary, whereas immigrant earnings exceeded those of the native-born in 1990, the situation had reversed by 2000 . The impression that declining relative earnings is a large city phenomenon is confirmed by the finding that the Pearson correlation between total city employment and the immigrant-native earnings difference changed from a statistically insignificant -0.282 
Table 1

Difference in the annual earnings of immigrants and natives employed in the hi-tech sector, ranked by 2001 city size

\begin{tabular}{|c|c|c|c|c|}
\hline City (CMA/CA) & Difference in 1990 & Difference in 1995 & Difference in 2000 & 2001 population \\
\hline Canada & $\$ 2,565$ & $\$ 272$ & $\$(632)$ & $30,007,094$ \\
\hline Toronto & $\$(2,561)$ & $\$(5,733)$ & $\$(9,772)$ & $4,682,897$ \\
\hline Montréal & $\$ 2,249$ & $\$(418)^{*}$ & $\$(2,450)$ & $3,426,350$ \\
\hline Vancouver & $\$ 1,521$ & $\$(3,453)$ & $\$(5,551)$ & $1,986,965$ \\
\hline Ottawa - Hull & $\$ 3,769$ & $\$ 3,471$ & $\$(261)^{*}$ & $1,063,664$ \\
\hline Calgary & $\$ 2,620$ & $\$(743)^{*}$ & $\$(3,723)$ & 951,395 \\
\hline Edmonton & $\$ 958$ & $\$ 278^{*}$ & $\$ 174 *$ & 937,845 \\
\hline Québec & $\$(781)^{*}$ & $\$(771)^{*}$ & $\$ 3,411$ & 682,757 \\
\hline Winnipeg & $\$(581)^{*}$ & $\$(1,596)$ & $\$(2,525)$ & 671,274 \\
\hline Hamilton & $\$ 3,528$ & $\$ 1,482$ & $\$(350)^{*}$ & 662,401 \\
\hline London & $\$ 3,747$ & $\$ 691^{*}$ & $\$(2,389)$ & 432,451 \\
\hline Kitchener & $\$ 1,535^{*}$ & $\$ 655^{*}$ & $\$(1,704)^{*}$ & 414,284 \\
\hline St Catharines - Niagara & $\$ 7,337$ & $\$ 4,083$ & $\$ 4,908$ & 377,009 \\
\hline Halifax & $\$ 8,484$ & $\$ 5,671$ & $\$ 3,197$ & 359,183 \\
\hline Victoria & $\$ 5,096$ & $\$ 333^{*}$ & $\$ 2,858$ & 311,902 \\
\hline Windsor & $\$ 1,344^{*}$ & $\$(1,199)^{*}$ & $\$ 69^{*}$ & 307,877 \\
\hline Oshawa & $\$ 7,121$ & $\$ 3,153$ & $\$ 2,176$ & 296,298 \\
\hline Saskatoon & $\$ 10,881$ & $\$ 7,172$ & $\$ 6,113$ & 225,927 \\
\hline Regina & $\$ 1,933^{*}$ & $\$ 1,610^{*}$ & $\$ 1,687^{*}$ & 192,800 \\
\hline St John's & $\$ 12,275$ & $\$ 11,366$ & $\$ 8,413$ & 172,918 \\
\hline Greater Sudbury & $\$ 4,217$ & $\$ 6,215$ & $\$ 10,392$ & 155,601 \\
\hline Sherbrooke & $\$ 868^{*}$ & $\$ 5,951$ & $\$(388)^{*}$ & 153,811 \\
\hline Barrie & $\$ 1,604^{*}$ & $\$ 1,467^{*}$ & $\$ 3,655$ & 148,480 \\
\hline Kelowna & $\$(1,750)^{*}$ & $\$(239)^{*}$ & $\$(3,497)$ & 147,739 \\
\hline Abbotsford & $\$ 744^{*}$ & $\$(2,204)^{*}$ & $\$(3,379)$ & 147,370 \\
\hline Kingston & $\$ 3,765$ & $\$ 6,146$ & $\$ 7,001$ & 146,838 \\
\hline Saint John & $\$ 6,647$ & $\$ 236^{*}$ & $\$ 9,644$ & 122,678 \\
\hline Thunder Bay & $\$ 3,486^{*}$ & $\$ 1,798^{*}$ & $\$ 13,412$ & 121,986 \\
\hline Moncton & $\$ 14,604$ & $\$ 2,613^{*}$ & $\$ 1,698^{*}$ & 117,727 \\
\hline Guelph & $\$ 1,165^{*}$ & $\$(71)^{*}$ & $\$ 4,967$ & 117,344 \\
\hline Chatham-Kent & $\$(3,475)^{*}$ & $\$ 19,988$ & $\$ 3,628^{*}$ & 107,709 \\
\hline Peterborough & $\$ 4,257^{*}$ & $\$ 1,767^{*}$ & $\$ 5,377^{*}$ & 102,423 \\
\hline Sarnia & $\$ 7,399$ & $\$ 6,393$ & $\$ 12,438$ & 88,331 \\
\hline Belleville & $\$ 8,482$ & $\$ 9,953$ & $\$ 10,620$ & 87,395 \\
\hline Kamloops & $\$ 1,716^{*}$ & $\$ 3,436^{*}$ & $\$ 5,958$ & 86,491 \\
\hline Brantford & $\$ 364^{*}$ & $\$ 4,901$ & $\$ 3,613^{*}$ & 86,417 \\
\hline Nanaimo & $\$ 1,608^{*}$ & $\$ 4,045$ & $\$ 5,103$ & 85,664 \\
\hline Prince George & $\$ 7,266$ & $\$ 11,162$ & $\$ 4,465^{*}$ & 85,035 \\
\hline Fredericton & $\$ 7,243$ & $\$ 321^{*}$ & $\$ 7,984$ & 81,346 \\
\hline Sault Ste Marie & $\$ 11,303$ & $\$ 9,325$ & $\$ 17,183$ & 78,908 \\
\hline Chilliwack & $\$(1,160)^{*}$ & $\$(931)^{*}$ & $\$ 3,427^{*}$ & 69,776 \\
\hline Kawartha Lakes & $\$ 4,491^{*}$ & $\$(5,954)^{*}$ & $\$ 3,668^{*}$ & 69,179 \\
\hline Red Deer & $\$ 1,498^{*}$ & $\$ 359^{*}$ & $\$(4,721)^{*}$ & 67,707 \\
\hline Lethbridge & $\$ 2,625^{*}$ & $\$ 6,445$ & $\$ 764 *$ & 67,374 \\
\hline
\end{tabular}

Excludes those attending school full-time, nonpermanent residents and those earning more than $\$ 500,000 /$ less than $\$ 500$ per year. *Indicates that the difference is not statistically significant at the $1 \%$ level. All others are significant at the $1 \%$ level.

SOURCE: Authors analysis of Census microdata.

in 1990 to a statistically significant -0.550 in 2000.

It is, however, important to reiterate that the data presented in Table 1 simply compare the raw or unadjusted earnings of immigrants and native-born hi-tech workers. One possible explanation for the observed difference between immigrants and the native-born is that the individual characteristics of these groups differ, and are changing. To account for this possibility, we 
used confidential census microdata and a wage equation regression framework to control for demographic and human capital characteristics of individuals. In the analysis that follows, we show that the patterns observed in the unadjusted earnings data are still visible even when we control for these differences.

\section{Overall Earnings Equations}

To examine whether demographic and human capital characteristics of individuals explain the observed geographic differences and changes in earnings of immigrants relative to native-born hi-tech workers, we employ the standard wage equation framework that is widely used by labour economists (see Kaufman and Hotchkiss 2003). Individual earnings are modelled as a function of various demographic and human capital attributes, controls for location (where appropriate), sector and occupation and immigrant status. Hence,

$$
\begin{aligned}
\ln \$= & \alpha+\beta_{1} \text { Demog }+\beta_{2} \text { Location }+\beta_{3} \text { Hitech } \\
& +\beta_{4} \text { Immigrant }+\beta_{5} \text { Hitech } * \text { Immigrant }+\varepsilon,
\end{aligned}
$$

where

- $\ln \$$ is the $\log$ of annual earnings (sum of wages, salaries and nonfarm self-employment income), $\log$ of annual wages and salaries, log of annual nonfarm self-employment income or $\log$ of weekly wages and salaries, in the year prior to the census (i.e., 1990/1995/2000);

- Demog is a vector of variables controlling for experience (years in the Canadian labour market in quadratic form $)^{4}$, years of education and dummy variables indicating female gender, marital status married, membership of a visible minority group, Aboriginal identity, inter-

4 We calculate 'years in the Canadian labour market' using the standard Mincerian experience calculation (age minus six minus years of education), except for immigrants for whom it is the lesser of years since landing in Canada and Mincerian experience. We use years in the Canadian labour market as an indicator of experience rather than age because previous findings have indicated that immigrants to Canada are increasingly unlikely to be rewarded for pre-immigration experience (see literature review above). Using age (in the quadratic form) changes the size, but not the sign of the coefficient. nal migrant status ${ }^{5}$, and part-time employment status;

- Location is a series of dummy variables for city (CMA/CA) of residence that account for the individual effect of geographical differences in labour markets ${ }^{6}$;

- Hitech is a dummy variable indicating employment in the hi-tech sector, that is, employment in either one of the 12 hi-tech industries or in one of the 33 hi-tech occupations. In regressions involving multiple cities we also include dummy variables for each of the 12 hitech subsectors to control for differences in economic structure ${ }^{7}$;

- Immigrant is a dummy variable indicating immigrant status;

- Hitech * Immigrant is a dummy variable indicating an individual who is an immigrant working in the hi-tech sector; and

- $\alpha$ is the intercept capturing what a person would earn with no other productivity-related characteristics, and $\varepsilon$ is a random error term.

Coefficients $\beta_{3}, \beta_{4}$ and $\beta_{5}$ are of special interest in this study, respectively, indicating the effect that hi-tech employment, immigrant status and the interaction of these two characteristics have on earnings and wages. Because we are modelling the log of earnings or wages, we interpret each of these coefficients as representing the percentage increase in earnings or wages resulting from a unit increase in the independent variable. So for example, in Table 2, the -0.046 in the 'log of annual earnings' column and in the 'dummy for immigrant' row may be interpreted as indicating that immigrants earn 4.6 percent less per year than nonimmigrants, other characteristics (such as years of schooling, experience and place of residence), being equal. We refer to this as the immigrant earnings penalty (or premium, if it is positive).

We include only those individuals who had been in the labour force since January 1st in the

5 An internal migrant is someone who lived in a different municipality (Census Sub-Division) five years ago.

6 The inclusion of regional dummy variables (for the Maritimes, Québec, Prairies, British Columbia and the north) does not change the results. Unless otherwise specified, residence outside one of the 43 largest CMA/CAs is the omitted category.

7 In these cases, employment in a hi-tech occupation but not in a hi-tech industry is the omitted category. 
Table 2

Determinants of earnings and wages, Canada, 2000

\begin{tabular}{|c|c|c|c|c|c|c|c|c|}
\hline & \multicolumn{2}{|c|}{ Log annual earnings } & \multicolumn{2}{|c|}{$\begin{array}{l}\text { Log annual self- } \\
\text { employment income }\end{array}$} & \multicolumn{2}{|c|}{$\begin{array}{l}\text { Log annual wages } \\
\text { and salary }\end{array}$} & \multicolumn{2}{|c|}{$\begin{array}{c}\text { Log weekly wages } \\
\text { and salary }\end{array}$} \\
\hline & B & $\begin{array}{l}\text { Standard } \\
\text { error }\end{array}$ & B & $\begin{array}{l}\text { Standard } \\
\text { error }\end{array}$ & B & $\begin{array}{l}\text { Standard } \\
\text { error }\end{array}$ & B & $\begin{array}{l}\text { Standard } \\
\text { error }\end{array}$ \\
\hline (Constant) & 8.375 & 0.003 & 8.569 & 0.019 & 8.331 & 0.003 & 4.965 & 0.003 \\
\hline Years in Canadian labour force & 0.053 & 0.000 & 0.031 & 0.001 & 0.055 & 0.000 & 0.039 & 0.000 \\
\hline $\begin{array}{l}\text { Years in Canadian labour force } \\
\text { squared }\end{array}$ & -0.001 & 0.000 & -0.001 & 0.000 & -0.001 & 0.000 & -0.001 & 0.000 \\
\hline Dummy for female & -0.279 & 0.001 & -0.417 & 0.006 & -0.282 & 0.001 & -0.285 & 0.001 \\
\hline Dummy for married & 0.175 & 0.001 & 0.121 & 0.006 & 0.181 & 0.001 & 0.142 & 0.001 \\
\hline Years of education & 0.085 & 0.000 & 0.068 & 0.001 & 0.088 & 0.000 & 0.074 & 0.000 \\
\hline Dummy for visible minority & -0.148 & 0.002 & -0.095 & 0.011 & -0.153 & 0.002 & -0.124 & 0.002 \\
\hline Dummy for Aboriginal identity & -0.327 & 0.002 & -0.079 & 0.018 & -0.352 & 0.002 & -0.122 & 0.002 \\
\hline Dummy for internal migrant & 0.023 & 0.001 & $-0.001^{*}$ & 0.008 & 0.020 & 0.001 & 0.033 & 0.001 \\
\hline $\begin{array}{l}\text { Dummy for mostly part time } \\
\text { last year }\end{array}$ & -0.972 & 0.001 & -0.834 & 0.007 & -0.981 & 0.001 & -0.700 & 0.001 \\
\hline Hi-tech by industry or occupation & 0.236 & 0.003 & $-0.027^{*}$ & 0.025 & 0.223 & 0.003 & 0.193 & 0.003 \\
\hline $\begin{array}{l}\text { Hi-tech immigrant by industry or } \\
\text { occupation }\end{array}$ & -0.019 & 0.003 & -0.070 & 0.018 & -0.019 & 0.004 & 0.010 & 0.003 \\
\hline Dummy for immigrant & -0.046 & 0.002 & -0.053 & 0.008 & -0.033 & 0.002 & -0.021 & 0.002 \\
\hline$N$ & \multicolumn{2}{|c|}{$2,779,404$} & \multicolumn{2}{|c|}{161,315} & \multicolumn{2}{|c|}{$2,468,695$} & \multicolumn{2}{|c|}{$2,465,416$} \\
\hline Adjusted $R^{2}$ & \multicolumn{2}{|c|}{0.342} & \multicolumn{2}{|c|}{0.193} & \multicolumn{2}{|c|}{0.370} & \multicolumn{2}{|c|}{0.300} \\
\hline
\end{tabular}

Dummy variables for CMA/CA of residence and 12 hi-tech industry subsectors were included in all regressions but are not reported here. Excludes those attending school full-time, nonpermanent residents and those earning more than $\$ 500,000$ per year/ $\$ 10,000$ per week, or less than $\$ 500$ per year $/ \$ 10$ per week.

*Indicates that the coefficient is not statistically significant at the $1 \%$ level. All other coefficients are significant at the $1 \%$ level.

SOURCE: Authors analysis of Census microdata.

year before the Census (i.e., for the 1991 data, those who have been in the labour force since January 1, 1990). We also exclude all those who were attending school on a full-time basis, and all nonpermanent residents (for instance, those in Canada on work or study permits). Finally, we also excluded very high (above $\$ 500,000 /$ year or $\$ 10,000 /$ week) and very low (below $\$ 500 /$ year or $\$ 10 /$ week) earnings, income or wages and salaries.

The demographic and human capital determinants of earnings and wages identified by the overall earnings equations are all as expected (see Table 2). Starting with total annual earnings, we note that Canadian labour market experience, being married or an internal migrant, and having more education are correlated with higher annual earnings, while being female, a member of a visible minority group, having Aboriginal identity, and working part-time are correlated with lower annual earnings. These findings are replicated in
Table 2 for annual self-employment income, for annual wages and salary and for weekly wages and salary. Our overall findings enjoy wide confirmation in the labour economics literature. For example, we find that each additional year of education results in approximately 8.5 percent higher earnings. Analyzing the 1973 Job Mobility Survey using the same ordinary least squared regression approach that we have, Lemieux and Card (2001) found that each year of education increased earnings by seven percent ${ }^{8}$. Any change since 1973 is consistent with the notion that returns to education have increased in the last three decades (Boudarbat et al. 2003).

8 Lemieux and Card (2001) argue that returns to education are considerably higher once one takes into account the fact that people who are more able to benefit from education are more likely to stay in school, college or university. We agree with them, but cannot adjust for these dynamics with the data we have available. 
The determinants of income for those in selfemployment appear to be somewhat different than the determinants of those earning wages and salaries. While total annual earnings, and annual and weekly wages and salary are higher for internal migrants, self-employment income is not higher for internal migrants. This makes sense; people may move for better paying jobs, but generally cannot take the networks that support self-employment with them.

Moving to the coefficients of specific interest in this study, we note that in 2000, immigrants overall received earnings and wages of between 2.1 percent and 5.3 percent less than otherwise comparable native-born working adults. The difference is greatest for selfemployment income (5.3 percent), reflecting the disadvantages faced by immigrants in the sectors in which they choose and are able to start up businesses, and in the relative success of those business ventures. Success in self-employment also depends on personal networking; apparently immigrants to Canada face a hard time in establishing self-employed ventures. The difference is smallest in terms of weekly wages (2.1 percent), suggesting that some immigrants are able to obtain close to equivalent pay rates, but fewer weeks of work, than native-born employees. We speculate that some immigrants may work more weeks and hours if they had the option.

A job in a hi-tech sector or occupation generally pays well; annual earnings, and weekly wages and salary are between 19 percent and 24 percent higher for hi-tech workers. However, self-employment income is not significantly higher for the hi-tech industry; this result may be influenced by our exclusion of very high incomes, which would exclude from our analysis any Canadian hi-tech entrepreneur 'millionaires'. Further, we also note that hi-tech immigrants receive about seven percent less self-employment income and salaries other things being equal. In other words, self-employed immigrants in the hitech industry do worse than self-employed immigrants in other sectors, and they do worse than self-employed natives in the hi-tech industry. This evidence suggests that hi-tech immigrants to Canada do not have the same possibilities for engaging in entrepreneurial activities as the 'argonauts' of Silicon Valley identified by Saxenian (2006).
How have these general determinants of earnings, income and wages changed over the decade of the 1990s? In Table 3 we repeat the 2000 regressions for 1990 and 1995 earnings, income and wages, respectively. However, we only report coefficients for the three variables of central interest here ${ }^{9}$. Consistent with findings in other studies, we find that the overall immigrant earnings/income/wage penalty increased over the decade, with almost all of the deterioration occurring between 1990 and 1995. The immigrant penalty increased from 0-4 percent to 2-5 percent. For annual earnings, the penalty increased from 2.2 percent to 4.6 percent; a 2.1 percent weekly wage and salary immigrant penalty arose from no penalty in 1990. At the same time, the earnings and wage premium for people employed in a hi-tech sector or occupation increased over the decade. The hi-tech earnings and wage premium increased from 16-21 percent to 19-24 percent over the decade. The income penalty of the self-employed in the hitech sector decreased. This is consistent with the tech boom of the 1990s, and an important question for analysis of the 2006 Census will be whether the 2000 premium survived the dotcom/telecommunications bust of the early years of the current decade.

Finally, there is evidence that the hi-tech immigrant earnings penalty may have narrowed over the decade. For annual earnings, the penalty narrowed from three percent to two percent while for weekly wages and salaries a one percent penalty in 1990 was eliminated by 1995 . In summary, across all of Canada and holding other things equal, immigrants do earn significantly less than nonimmigrants, and this trend has intensified over the last decade. More positively, in the hi-tech sector the gap between immigrants and native-born is smaller and may be declining.

\section{Earnings Differences by City Type}

Our visual inspection of the unadjusted differences in immigrant and native-born earnings over the 1990s suggested that the largest differences were increasingly to be found in the

9 Complete regression output is available from the lead author on request. 
Table 3

Determinants of earnings and wages, Canada, 1990-2000

\begin{tabular}{|c|c|c|c|c|c|c|}
\hline & \multicolumn{2}{|c|}{1990} & \multicolumn{2}{|c|}{1995} & \multicolumn{2}{|c|}{2000} \\
\hline & B & Standard error & B & Standard error & B & Standard error \\
\hline & \multicolumn{6}{|c|}{ Log annual earnings } \\
\hline Hi-tech by industry or occupation & 0.205 & 0.003 & 0.229 & 0.003 & 0.236 & 0.003 \\
\hline Hi-tech immigrant by industry or occupation & -0.030 & 0.004 & -0.025 & 0.004 & -0.019 & 0.003 \\
\hline Dummy for immigrant & -0.022 & 0.002 & -0.042 & 0.002 & -0.046 & 0.002 \\
\hline$N$ & \multicolumn{2}{|c|}{$2,563,415$} & \multicolumn{2}{|c|}{$2,602,768$} & \multicolumn{2}{|c|}{$2,779,404$} \\
\hline \multirow[t]{2}{*}{ Adjusted $R^{2}$} & \multicolumn{2}{|c|}{0.340} & \multicolumn{2}{|c|}{0.337} & \multicolumn{2}{|c|}{0.342} \\
\hline & \multicolumn{6}{|c|}{ Log annual self-employment income } \\
\hline Hi-tech by industry or occupation & -0.109 & 0.037 & $-0.040^{*}$ & 0.029 & $-0.027^{*}$ & 0.025 \\
\hline Hi-tech immigrant by industry or occupation & $-0.023^{*}$ & 0.024 & $-0.033^{*}$ & 0.020 & -0.070 & 0.018 \\
\hline Dummy for immigrant & -0.042 & 0.009 & -0.055 & 0.008 & -0.053 & 0.008 \\
\hline$N$ & \multicolumn{2}{|c|}{111,486} & \multicolumn{2}{|c|}{148,431} & \multicolumn{2}{|c|}{161,315} \\
\hline \multirow[t]{2}{*}{ Adjusted $R^{2}$} & \multicolumn{2}{|c|}{0.204} & \multicolumn{2}{|c|}{0.195} & \multicolumn{2}{|c|}{0.193} \\
\hline & \multicolumn{6}{|c|}{ Log annual wages and salary } \\
\hline Hi-tech by industry or occupation & 0.200 & 0.003 & 0.211 & 0.003 & 0.223 & 0.003 \\
\hline $\mathrm{Hi}$-tech immigrant by industry or occupation & -0.030 & 0.004 & -0.026 & 0.004 & -0.019 & 0.004 \\
\hline Dummy for immigrant & -0.016 & 0.002 & -0.029 & 0.002 & -0.033 & 0.002 \\
\hline$N$ & \multicolumn{2}{|c|}{$2,325,924$} & \multicolumn{2}{|c|}{$2,308,159$} & \multicolumn{2}{|c|}{$2,468,695$} \\
\hline \multirow[t]{2}{*}{ Adjusted $R^{2}$} & \multicolumn{2}{|c|}{0.360} & \multicolumn{2}{|c|}{0.365} & \multicolumn{2}{|c|}{0.370} \\
\hline & \multicolumn{6}{|c|}{ Log weekly wages and salary } \\
\hline Hi-tech by industry or occupation & 0.161 & 0.003 & 0.185 & 0.003 & 0.193 & 0.003 \\
\hline Hi-tech immigrant by industry or occupation & -0.011 & 0.004 & $-0.006^{*}$ & 0.004 & 0.010 & 0.003 \\
\hline Dummy for immigrant & $-0.003^{*}$ & 0.001 & -0.015 & 0.002 & -0.021 & 0.002 \\
\hline$N$ & \multicolumn{2}{|c|}{$2,319,674$} & \multicolumn{2}{|c|}{$2,310,136$} & \multicolumn{2}{|c|}{$2,465,416$} \\
\hline Adjusted $R^{2}$ & \multicolumn{2}{|c|}{0.295} & \multicolumn{2}{|c|}{0.307} & & .300 \\
\hline
\end{tabular}

Demographic and human capital variables and dummy variables for CMA/CA of residence and 12 hi-tech industry subsectors were included in all regressions but are not reported here. Excludes those attending school full-time, nonpermanent residents and those earning more than $\$ 500,000$ per year $/ \$ 10,000$ per week or less than $\$ 500$ per year $/ \$ 10$ per week.

*Indicates that the coefficient is not statistically significant at the $1 \%$ level. All other coefficients are significant at the $1 \%$ level.

SOURCE: Authors analysis of Census microdata.

largest cities (see Table 1). While our literature review suggested that this was likely, it would be a mistake to think of this relationship as simply a size-based one. In order to understand the relationship between relative earnings of hi-tech immigrants and the urban hierarchy, we used a cluster analysis to identify groups of cities sharing common characteristics with respect to the employment of immigrants in the hi-tech sector. We grouped the 43 largest cities using the Ward's cluster method, with z-score standardization of four variables, each derived from location quotients depicting the extent to which:

- the hi-tech sector is locally concentrated;

- immigrants are concentrated in the city;

- immigrants in the hi-tech sector are concentrated in the city; and
- immigrants in the city are concentrated in the hi-tech sector.

We tried several iterations of this cluster process, and each cluster analysis identified the five biggest cities, a second tier of midsized cities divided into those with hi-tech specialization and other midsized cities, and a tier of smaller cities without much hi-tech activity or immigrant presence. The striking point about this analysis is that we can depict a great deal about the overall urban geography of Canada's major and midsized cities, simply by examining the characteristics of hi-tech immigrant employment (see Table 4).

Differences in unadjusted immigrant and native-born earnings across these city clusters were immediately apparent; in most of the 
Table 4

Cluster analysis of cities based on characteristics of employment of immigrants in the hi-tech industry

\begin{tabular}{|c|c|c|c|}
\hline Cluster (\# of cities) & CMA/CAs & Geographic characteristics of cities & 2000 hi-tech earnings difference \\
\hline Big 5 cities ( 5 ) & $\begin{array}{l}\text { Calgary, Montréal, Ottawa, Toronto, } \\
\text { Vancouver }\end{array}$ & $\begin{array}{l}\text { Major metropolitan areas of } 1 \\
\text { million plus }\end{array}$ & Immigrants earn less in 4 of 5 cities \\
\hline Tech cities (10) & $\begin{array}{l}\text { Abbotsford, Barrie, Edmonton, } \\
\text { Guelph, Hamilton, Kitchener, } \\
\text { London, Oshawa, Victoria, } \\
\text { Winnipeg }\end{array}$ & $\begin{array}{l}\text { Metropolitan-edge, major } 401 \\
\text { corridor and major provincial } \\
\text { capitals, typically of } 100,000 \\
\text { plus population }\end{array}$ & $\begin{array}{l}\text { Immigrants earn less in } 3 \text {, same in } \\
3 \text { and more in } 4 \text { cities }\end{array}$ \\
\hline Midsized cities (14) & $\begin{array}{l}\text { Belleville, Chilliwack, Fredericton, } \\
\text { Halifax, Kawartha Lakes, Kingston, } \\
\text { Lethbridge, Nanaimo, } \\
\text { Peterborough, Québec, Saint John, } \\
\text { Sherbrooke, St. John's, Windsor }\end{array}$ & Diverse group of midsized cities & $\begin{array}{l}\text { Immigrants earn more in } 8 \text { and } \\
\text { same in } 6 \text { cities }\end{array}$ \\
\hline Smaller cities (14) & $\begin{array}{l}\text { Brantford, Chatham-Kent, Greater } \\
\text { Sudbury, Kamloops, Kelowna, } \\
\text { Moncton, Prince George, Red Deer, } \\
\text { Regina, Sarnia, Saskatoon, Sault } \\
\text { Ste. Marie, St. Catharines-Niagara, } \\
\text { Thunder Bay }\end{array}$ & $\begin{array}{l}\text { Typically smaller and more } \\
\text { isolated midsized cities }\end{array}$ & $\begin{array}{l}\text { Immigrants earn more in } 7 \text {, same in } \\
6 \text { and less in } 1 \text { cities }\end{array}$ \\
\hline
\end{tabular}

SOURCE: Author's analysis of Statistics Canada, Custom Tabulation.

smaller and midsized cities immigrants in the hi-tech sector enjoyed above or at average earnings in comparison to native-born workers in the same sector. In what follows, we repeat the regressions for annual earnings and weekly wages and salary for each city cluster in order to determine whether these differences persist once we control for demographic and human capital characteristics. Results for the three coefficients of central interest to this study are presented in Tables 5 and 6. Although not reported in the tables, we found that the coefficients for experience, gender, marital status, education, Aboriginal identity and part-time employment are all of the expected sign and significance. However, it does appear that visible minorities receive a larger earnings and wage penalty in the big five cities. This finding is consistent with Pendukar and Pendukar (2002); it likely reflects social dynamics for which we cannot control and that are beyond the scope of this study, such as the possibility that minority 'ghettos' are forming in some of Canada's largest cities.

Immigrants earn less than the native-born in the big five and tech cities, but not significantly less in the midsized and smaller cities (see Table 5). In big five cities, at 7.1 percent, the immigrant annual earnings penalty is twice as large as the penalty in the tech cities (3.3 percent).
The contrast is equally sharp when we examine weekly wages and salary; immigrants receive 4.5 percent less in the big five cities and one percent less in the tech cities, but 2.2 percent more in the midsized cities and about the same (the 1.3 percent premium is not statistically significant) in the smaller cities (see Table 6). There was an important shift over the 1990s; while there was a gap in the immigrant earnings penalty between the big five and other city clusters in 1990, this gap widened dramatically between 1990 and 1995. The immigrants earning penalty in the big five cities nearly doubled from 4.3 percent to 7.1 percent during this time (Table 5). Table 6 indicates a similar timing in the evolution of the immigrant weekly wages and salary penalty; the gap between the big five cities and other city clusters was in place in 1990, but widened sharply between 1990 and 1995 .

These findings are all consistent with the notion that immigrants, in general, do relatively less well at or near the top of the urban hierarchy. However, we observe no major differences in the hi-tech sector or occupation premium across city clusters; both hi-tech annual earnings and weekly wage premiums increased over the decade. We also observe no clear pattern in the hi-tech immigrant penalty; an annual hi-tech immigrant earnings penalty emerged in 
Table 5

Determinants of log annual earnings by city cluster, 1990-2000

\begin{tabular}{|c|c|c|c|c|c|c|}
\hline & \multicolumn{2}{|c|}{1990} & \multicolumn{2}{|c|}{1995} & \multicolumn{2}{|c|}{2000} \\
\hline & B & Standard error & B & Standard error & B & Standard error \\
\hline & \multicolumn{6}{|c|}{ Big 5 cities } \\
\hline Hi-tech by industry or occupation & 0.171 & 0.004 & 0.206 & 0.203 & 0.219 & 0.004 \\
\hline Hi-tech immigrant by industry or occupation & $-0.004^{*}$ & 0.005 & $-0.007^{*}$ & -0.004 & -0.013 & 0.004 \\
\hline Dummy for immigrant & -0.043 & 0.002 & -0.069 & -0.072 & -0.071 & 0.002 \\
\hline$N$ & \multicolumn{2}{|c|}{972,296} & \multicolumn{2}{|c|}{$1,002,704$} & \multicolumn{2}{|c|}{$1,097,014$} \\
\hline \multirow[t]{2}{*}{ Adjusted $R^{2}$} & \multicolumn{2}{|c|}{0.324} & \multicolumn{2}{|c|}{0.328} & \multicolumn{2}{|c|}{0.332} \\
\hline & \multicolumn{6}{|c|}{ Tech cities } \\
\hline Hi-tech by industry or occupation & 0.172 & 0.007 & 0.194 & 0.008 & 0.195 & 0.007 \\
\hline Hi-tech immigrant by industry or occupation & $-0.006^{*}$ & 0.010 & -0.025 & $0.011^{*}$ & $-0.007^{*}$ & 0.009 \\
\hline Dummy for immigrant & -0.026 & 0.004 & -0.030 & 0.004 & -0.033 & 0.004 \\
\hline$N$ & \multicolumn{2}{|c|}{347,942} & \multicolumn{2}{|c|}{351,218} & \multicolumn{2}{|c|}{389,580} \\
\hline \multirow[t]{2}{*}{ Adjusted $R^{2}$} & \multicolumn{2}{|c|}{0.353} & \multicolumn{2}{|c|}{0.358} & \multicolumn{2}{|c|}{0.368} \\
\hline & \multicolumn{6}{|c|}{ Midsized cities } \\
\hline Hi-tech by industry or occupation & 0.175 & 0.009 & 0.211 & 0.010 & 0.210 & 0.009 \\
\hline Hi-tech immigrant by industry or occupation & $-0.036^{*}$ & 0.020 & $-0.043^{*}$ & 0.021 & $-0.003^{*}$ & 0.018 \\
\hline Dummy for immigrant & $0.003^{*}$ & 0.007 & $-0.010^{*}$ & 0.007 & $-0.009^{*}$ & 0.007 \\
\hline$N$ & \multicolumn{2}{|c|}{209,896} & \multicolumn{2}{|c|}{208,178} & \multicolumn{2}{|c|}{223,660} \\
\hline \multirow[t]{2}{*}{ Adjusted $R^{2}$} & \multicolumn{2}{|c|}{0.349} & \multicolumn{2}{|c|}{0.352} & \multicolumn{2}{|c|}{0.351} \\
\hline & \multicolumn{6}{|c|}{ Smaller cities } \\
\hline Hi-tech by industry or occupation & 0.192 & 0.012 & 0.197 & 0.012 & 0.224 & 0.011 \\
\hline Hi-tech immigrant by industry or occupation & $-0.031^{*}$ & 0.021 & $-0.013^{*}$ & 0.022 & -0.055 & 0.021 \\
\hline Dummy for immigrant & $-0.014^{*}$ & 0.006 & $-0.015^{*}$ & 0.007 & $-0.004^{*}$ & 0.007 \\
\hline$N$ & \multicolumn{2}{|c|}{160,907} & \multicolumn{2}{|c|}{162,742} & \multicolumn{2}{|c|}{173,027} \\
\hline Adjusted $R^{2}$ & \multicolumn{2}{|c|}{0.370} & \multicolumn{2}{|c|}{0.373} & & 363 \\
\hline
\end{tabular}

Demographic and human capital variables and dummy variables for CMA/CA of residence (Toronto, Barrie, Kawartha Lakes/Lindsay and Brantford, respectively, are omitted) and 12 hi-tech industry subsectors were included in all regressions but are not reported here. Excludes those attending school full-time, nonpermanent residents and those earning more than $\$ 500,000 /$ less than $\$ 500$ per year.

*Indicates that the coefficient is not statistically significant at the $1 \%$ level. All other coefficients are significant at the $1 \%$ level.

SOURCE: Authors analysis of Census microdata.

the big five and smaller city clusters in 2000, but there was no weekly hi-tech immigrant wage penalty in any city class at any time during the decade. So, while we can say that place in the urban hierarchy helps understand immigrant's relative labour market outcomes in general, alone it is not a sufficient explanation for the observed variation in sector-specific earnings and wages across Canadian cities. To explore this idea further, in the final empirical section we examine immigrant earnings in individual cities in the big five city cluster.

\section{Big Five Cities' Earning Equations}

The immigrant earnings and wage penalty is significantly larger in the big five city cluster. In this final empirical section, we look inside this cluster to examine whether there are differences in the labour market performance of hi-tech immigrants in particular cities. In Tables 7 and 8, we report separate annual earnings and weekly wage regressions for Calgary, Montréal, Ottawa, Toronto and Vancouver. The coefficients for experience, gender, marital status, education, visible minority status, Aboriginal identity and parttime employment (not reported in the Tables) are all of the expected sign and significance.

Among the big five cities, there are very few systematic differences in the immigrant earnings and wage penalty; this finding supports the notion that the generalized explanationimmigrants are in competition with each other in places at the top of the urban hierarchy-holds within this class of cities. In terms of annual 


\begin{tabular}{|c|c|c|c|c|c|c|}
\hline & \multicolumn{2}{|c|}{1990} & \multicolumn{2}{|c|}{1995} & \multicolumn{2}{|c|}{2000} \\
\hline & B & Standard error & B & Standard error & B & Standard error \\
\hline & \multicolumn{6}{|c|}{ Big 5 cities } \\
\hline $\mathrm{Hi}$-tech by industry or occupation & 0.138 & 0.004 & 0.168 & 0.004 & 0.183 & 0.004 \\
\hline Hi-tech immigrant by industry or occupation & $-0.004^{*}$ & 0.004 & $0.001^{*}$ & 0.004 & $0.006^{*}$ & 0.004 \\
\hline Dummy for immigrant & -0.015 & 0.002 & -0.038 & 0.002 & -0.045 & 0.002 \\
\hline$N$ & \multicolumn{2}{|c|}{876,924} & \multicolumn{2}{|c|}{882,833} & \multicolumn{2}{|c|}{965,915} \\
\hline \multirow[t]{2}{*}{ Adjusted $R^{2}$} & \multicolumn{2}{|c|}{0.286} & \multicolumn{2}{|c|}{0.302} & \multicolumn{2}{|c|}{0.296} \\
\hline & \multicolumn{6}{|c|}{ Tech cities } \\
\hline $\mathrm{Hi}$-tech by industry or occupation & 0.138 & 0.006 & 0.156 & 0.007 & 0.163 & 0.006 \\
\hline $\mathrm{Hi}$-tech immigrant by industry or occupation & $-0.009^{*}$ & 0.009 & $-0.017^{*}$ & 0.010 & $0.013^{*}$ & 0.009 \\
\hline Dummy for immigrant & $0.001^{*}$ & 0.003 & $-0.003^{*}$ & 0.004 & -0.011 & 0.004 \\
\hline$N$ & \multicolumn{2}{|c|}{319,414} & \multicolumn{2}{|c|}{314,093} & \multicolumn{2}{|c|}{349,184} \\
\hline \multirow[t]{2}{*}{ Adjusted $R^{2}$} & \multicolumn{2}{|c|}{0.322} & \multicolumn{2}{|c|}{0.347} & \multicolumn{2}{|c|}{0.342} \\
\hline & \multicolumn{6}{|c|}{ Midsized cities } \\
\hline $\mathrm{Hi}$-tech by industry or occupation & 0.142 & 0.008 & 0.172 & 0.008 & 0.177 & 0.008 \\
\hline $\mathrm{Hi}$-tech immigrant by industry or occupation & $-0.017^{*}$ & 0.018 & $-0.018^{*}$ & 0.019 & $0.037^{*}$ & 0.017 \\
\hline Dummy for immigrant & 0.036 & 0.006 & 0.020 & 0.007 & 0.022 & 0.007 \\
\hline $\mathrm{N}$ & \multicolumn{2}{|c|}{193,873} & \multicolumn{2}{|c|}{189,360} & \multicolumn{2}{|c|}{202,802} \\
\hline \multirow[t]{2}{*}{ Adjusted $R^{2}$} & \multicolumn{2}{|c|}{0.314} & \multicolumn{2}{|c|}{0.333} & \multicolumn{2}{|c|}{0.320} \\
\hline & \multicolumn{6}{|c|}{ Smaller cities } \\
\hline $\mathrm{Hi}$-tech by industry or occupation & 0.162 & 0.010 & 0.161 & 0.010 & 0.189 & 0.010 \\
\hline $\mathrm{Hi}$-Tech immigrant by industry or occupation & $-0.011^{*}$ & 0.019 & $0.009^{*}$ & 0.020 & $-0.004^{*}$ & 0.020 \\
\hline Dummy for immigrant & $0.003^{*}$ & 0.006 & $0.007^{*}$ & 0.006 & $0.013^{*}$ & 0.007 \\
\hline$N$ & \multicolumn{2}{|c|}{148,108} & \multicolumn{2}{|c|}{146,796} & \multicolumn{2}{|c|}{155,740} \\
\hline Adjusted $R^{2}$ & \multicolumn{2}{|c|}{0.338} & \multicolumn{2}{|c|}{0.363} & & .337 \\
\hline
\end{tabular}

Demographic and human capital variables and dummy variables for CMA/CA of residence (Toronto, Barrie, Kawartha Lakes/Lindsay and Brantford respectively are omitted) and 12 hi-tech industry subsectors were included in all regressions but are not reported here. Excludes those attending school full-time, nonpermanent residents and those earning more than $\$ 10,000 /$ less than $\$ 10$ per week. *Indicates that the coefficient is not statistically significant at the $1 \%$ level. All other coefficients are significant at the $1 \%$ level. SOURCE: Authors analysis of Census microdata.

earnings, the immigrant earnings penalty varies from 6.7 percent in Calgary to 9.1 percent in Vancouver (see Table 7). In other words, there is a larger gap between the earnings of immigrants and nonimmigrants in Vancouver than in other cities in that year. However, Table 7 suggests that there was no clear hierarchy across the five largest cities over the decade. In 1995 and 1990, the largest immigrant penalty was in Montréal (9.0 percent and 6.2 percent, respectively). The immigrant annual earnings penalty widened in all five cities between 1990 and 1995, while there is no clear trend from 1995 to 2000 (see Table 7). The immigrant weekly wage penalty also increased more sharply from 1990 to 1995, but there are indications that it continued to widen between 1995 and 2000 (see Table 8).
However, there was very little variation across the five cities with respect to the immigrant weekly wages penalty in 2000 (see Table 8), again reinforcing the idea that the overall immigrant penalty applies to all cities in this class.

In contrast, when we examine the sectorspecific earnings and wage coefficients, we find considerable systematic variation within this class of cities. The hi-tech earnings and wage premium was significantly larger in Ottawa (see Tables 7 and 8) in 2000 than in other cities; 21.4 percent versus 13.5-17.5 percent in the case of annual earnings. This is something new; Tables 7 and 8 indicate that the hi-tech earnings and wage premium was much less variable across the big five cities in 1990 and 1995, and that 2000 
Table 7

Determinants of log annual earnings, largest cities, 1990-2000

\begin{tabular}{|c|c|c|c|c|c|c|}
\hline & \multicolumn{2}{|c|}{1990} & \multicolumn{2}{|c|}{1995} & \multicolumn{2}{|c|}{2000} \\
\hline & B & Standard error & B & Standard error & B & Standard error \\
\hline & \multicolumn{6}{|c|}{ Calgary } \\
\hline Hi-tech by industry or occupation & 0.125 & 0.009 & 0.131 & 0.009 & 0.168 & 0.008 \\
\hline Hi-tech immigrant by industry or occupation & $0.024^{*}$ & 0.020 & 0.048 & 0.019 & $0.007^{*}$ & 0.016 \\
\hline Dummy for immigrant & -0.057 & 0.009 & -0.087 & 0.009 & -0.067 & 0.009 \\
\hline$N$ & \multicolumn{2}{|r|}{77,261} & \multicolumn{2}{|c|}{82,312} & \multicolumn{2}{|c|}{98,216} \\
\hline \multirow[t]{2}{*}{ Adjusted $R^{2}$} & \multicolumn{2}{|c|}{0.338} & \multicolumn{2}{|c|}{0.348} & \multicolumn{2}{|c|}{0.362} \\
\hline & \multicolumn{6}{|c|}{ Montréal } \\
\hline Hi-tech by industry or occupation & 0.136 & 0.005 & 0.156 & 0.005 & 0.175 & 0.004 \\
\hline Hi-tech immigrant by industry or occupation & 0.050 & 0.011 & 0.040 & 0.011 & 0.035 & 0.010 \\
\hline Dummy for immigrant & -0.062 & 0.005 & -0.090 & 0.005 & -0.081 & 0.005 \\
\hline$N$ & \multicolumn{2}{|c|}{282,529} & \multicolumn{2}{|c|}{280,941} & \multicolumn{2}{|c|}{296,513} \\
\hline \multirow[t]{2}{*}{ Adjusted $R^{2}$} & \multicolumn{2}{|c|}{0.310} & \multicolumn{2}{|c|}{0.297} & \multicolumn{2}{|c|}{0.300} \\
\hline & \multicolumn{6}{|c|}{ Ottawa } \\
\hline Hi-tech by industry or occupation & 0.116 & 0.007 & 0.135 & 0.007 & 0.214 & 0.007 \\
\hline $\mathrm{Hi}$-tech immigrant by industry or occupation & $0.009 *$ & 0.016 & 0.086 & 0.016 & 0.065 & 0.014 \\
\hline Dummy for immigrant & -0.044 & 0.008 & -0.065 & 0.009 & -0.070 & 0.009 \\
\hline$N$ & \multicolumn{2}{|r|}{91,721} & \multicolumn{2}{|c|}{93,374} & \multicolumn{2}{|c|}{97,936} \\
\hline \multirow[t]{2}{*}{ Adjusted $R^{2}$} & \multicolumn{2}{|c|}{0.375} & \multicolumn{2}{|c|}{0.376} & \multicolumn{2}{|c|}{0.360} \\
\hline & \multicolumn{6}{|c|}{ Toronto } \\
\hline Hi-tech by industry or occupation & 0.107 & 0.005 & 0.092 & 0.005 & 0.160 & 0.004 \\
\hline $\mathrm{Hi}$-tech immigrant by industry or occupation & $-0.009^{*}$ & 0.007 & $-0.006^{*}$ & 0.007 & -0.023 & 0.006 \\
\hline dummy for immigrant & -0.036 & 0.003 & -0.069 & 0.004 & -0.073 & 0.003 \\
\hline$N$ & \multicolumn{2}{|c|}{366,094} & & 78,822 & & 27,315 \\
\hline \multirow[t]{2}{*}{ Adjusted $R^{2}$} & & 0.307 & & 0.320 & & 0.324 \\
\hline & & & & ncouver & & \\
\hline Hi-tech by industry or occupation & 0.114 & 0.008 & 0.105 & 0.007 & 0.135 & 0.007 \\
\hline Hi-tech immigrant by industry or occupation & $0.031^{*}$ & 0.013 & $0.012 *$ & 0.012 & 0.038 & 0.011 \\
\hline Dummy for immigrant & -0.052 & 0.005 & -0.083 & 0.006 & -0.091 & 0.006 \\
\hline$N$ & & 54,691 & & 57,255 & & 77,035 \\
\hline Adjusted $R^{2}$ & & 0.321 & & 0.331 & & 0.337 \\
\hline
\end{tabular}

Demographic and human capital variables were included in all regressions but are not reported here. Excludes those attending school full-time, nonpermanent residents and those earning more than $\$ 500,000 /$ less than $\$ 500$ per year.

*Indicates that the coefficient is not statistically significant at the $1 \%$ level. All other coefficients are significant at the $1 \%$ level. SOURCE: Authors analysis of Census microdata.

was the only year in which Ottawa had a much larger hi-tech earnings or wage premium. These findings may reflect the rapid expansion of the Ottawa telecommunications and related activities during the 'tech bubble' of the late 1990s.

However, further evidence suggests that the regulation of the Ottawa hi-tech labour market may diverge from that in other cities. There is strong evidence that immigrants employed in the hi-tech sector share in the benefits of the Ottawa cluster in a way they do not in other cities. In 2000, immigrants in the hi-tech sector received an earnings premium of 6.5 percent, which was almost large enough to eliminate the 7.0 percent wage penalty received by all immigrants in the Ottawa labour market (see Table 7). In other words, immigrants in hi-tech employment could expect to earn as much as native-born employees in the same sector, other things being equal. In the case of weekly wages and salaries, immigrants in the hi-tech sector actually received more than nonimmigrants (Table 8). This pattern was established in 1995, and is not found in other large cities. 


\begin{tabular}{|c|c|c|c|c|c|c|}
\hline & \multicolumn{2}{|c|}{1990} & \multicolumn{2}{|c|}{1995} & \multicolumn{2}{|c|}{2000} \\
\hline & B & Standard error & B & Standard error & B & Standard error \\
\hline & \multicolumn{6}{|c|}{ Calgary } \\
\hline Hi-tech by industry or occupation & 0.109 & 0.008 & 0.130 & 0.008 & 0.170 & 0.007 \\
\hline Hi-tech immigrant by industry or occupation & $0.043^{*}$ & 0.018 & $0.037^{*}$ & 0.017 & $0.033^{*}$ & 0.015 \\
\hline Dummy for immigrant & -0.048 & 0.008 & -0.051 & 0.008 & -0.056 & 0.008 \\
\hline$N$ & \multicolumn{2}{|c|}{69,722} & \multicolumn{2}{|c|}{71,691} & \multicolumn{2}{|c|}{85,963} \\
\hline \multirow[t]{2}{*}{ Adjusted $R^{2}$} & \multicolumn{2}{|c|}{0.310} & \multicolumn{2}{|c|}{0.342} & \multicolumn{2}{|c|}{0.332} \\
\hline & \multicolumn{6}{|c|}{ Montréal } \\
\hline Hi-tech by industry or occupation & 0.125 & 0.004 & 0.151 & 0.004 & 0.174 & 0.004 \\
\hline Hi-tech immigrant by industry or occupation & 0.035 & 0.010 & 0.055 & 0.010 & 0.052 & 0.009 \\
\hline Dummy for immigrant & -0.022 & 0.004 & -0.047 & 0.005 & -0.048 & 0.005 \\
\hline$N$ & \multicolumn{2}{|c|}{255,785} & \multicolumn{2}{|c|}{251,394} & \multicolumn{2}{|c|}{264,802} \\
\hline \multirow[t]{2}{*}{ Adjusted $R^{2}$} & \multicolumn{2}{|c|}{0.277} & \multicolumn{2}{|c|}{0.270} & \multicolumn{2}{|c|}{0.264} \\
\hline & \multicolumn{6}{|c|}{ Ottawa } \\
\hline Hi-tech by industry or occupation & 0.096 & 0.006 & 0.136 & 0.006 & 0.204 & 0.006 \\
\hline Hi-tech immigrant by industry or occupation & $0.020^{*}$ & 0.014 & 0.060 & 0.014 & 0.098 & 0.013 \\
\hline Dummy for immigrant & $-0.017^{*}$ & 0.007 & -0.030 & 0.008 & -0.049 & 0.009 \\
\hline$N$ & \multicolumn{2}{|c|}{84,263} & \multicolumn{2}{|c|}{83,623} & \multicolumn{2}{|c|}{87,900} \\
\hline \multirow[t]{2}{*}{ Adjusted $R^{2}$} & \multicolumn{2}{|c|}{0.350} & \multicolumn{2}{|c|}{0.362} & \multicolumn{2}{|c|}{0.338} \\
\hline & \multicolumn{6}{|c|}{ Toronto } \\
\hline $\mathrm{Hi}$-tech by industry or occupation & 0.101 & 0.004 & 0.104 & 0.004 & 0.172 & 0.004 \\
\hline Hi-Tech immigrant by industry or occupation & -0.020 & 0.006 & $-0.007^{*}$ & 0.006 & -0.016 & 0.006 \\
\hline Dummy for immigrant & -0.008 & 0.003 & -0.038 & 0.003 & -0.048 & 0.003 \\
\hline$N$ & \multicolumn{2}{|c|}{329,906} & & 2,473 & & 4,499 \\
\hline \multirow[t]{2}{*}{ Adjusted $R^{2}$} & & .270 & & .295 & & .289 \\
\hline & & & & couver & & \\
\hline Hi-tech by industry or occupation & 0.103 & 0.007 & 0.107 & 0.007 & 0.153 & 0.006 \\
\hline Hi-tech immigrant by industry or occupation & 0.049 & 0.012 & $0.010^{*}$ & 0.011 & 0.038 & 0.010 \\
\hline Dummy for immigrant & -0.031 & 0.005 & -0.040 & 0.005 & -0.054 & 0.005 \\
\hline$N$ & & 7,248 & & 3,652 & & 2,752 \\
\hline Adjusted $R^{2}$ & & .273 & & .295 & & .295 \\
\hline
\end{tabular}

Demographic and human capital variables were included in all regressions but are not reported here. Excludes those attending school full-time, nonpermanent residents and those earning more than $\$ 10,000 /$ less than $\$ 10$ per week.

*Indicates that the coefficient is not statistically significant at the $1 \%$ level. All other coefficients are significant at the $1 \%$ level.

SOURCE: Authors analysis of Census microdata.

In contrast, while the hi-tech immigrant earnings premium is positive in Montréal and Vancouver (3.5 and 3.8 percent respectively), it is not large enough to overcome the overall immigrant penalty in these cities $(8.1$ and 9.1 percent, respectively). Hence, immigrants in hi-tech employment can expect to earn less than otherwise similar nonimmigrants. The contrast is even sharper in the case of Toronto, where the hi-tech immigrant wage premium actually turned negative in 2000. This means that immigrants in the hi-tech sector can expect to earn 2.3 percent less than immigrants in other sectors, in addition to earning 7.3 percent less than native-born employees in the same sector or occupation. It is this finding that lies behind the observed large gap between immigrant and native-born earnings in Toronto noted in Table 1.

In summary, this section has identified some significant geographic differences in the relative earnings of immigrants and native-born Canadians in hi-tech employment across the cities at the top of the urban hierarchy. In particular, the Toronto labour market, despite whatever other advantages it may offer, does penalize immigrants relative to the native-born in the hi-tech sector. In contrast, the Ottawa labour market at the end of the last decade, was a place where immigrants in the hi-tech sector earned as much as nonimmigrants in the hi-tech sector. 


\section{Conclusion and Policy Implications}

The central empirical contribution of this paper is that we have shown that labour market outcomes for immigrants relative to nonimmigrants vary from city to city, even when we control for individual characteristics and economic sector. First, we showed that over the 1990s, earnings of immigrants declined relative to those of the native-born, especially in the period 19901995. This trend was most pronounced in the largest cities. Using confidential Census microdata, we found that the immigrant wage and earnings penalty does indeed persist even when we control for demographic and human capital characteristics. In 2000, the earnings and wage penalty for immigrants, regardless of which sector they worked in, was largest in the larger cities, including precisely those cities that are the predominant destination of immigrants to Canada.

It might thus be said that the immigrant earnings penalty in largest cities is driving the immigrant earnings penalty observed across the nation. These findings enjoyed wide support in our literature review, which noted the increasing divergence between immigrant and nonimmigrant earnings in Canada over the decade of the 1990s. While this literature has generally not addressed the question of geographic differences in outcomes, recent writings from labour economists provide a powerful argument as to why immigrants do not depress the earnings of locals, but may depress the earnings of other immigrants already in place. This literature argues that immigrants are substitutes for other immigrants, and are hence in competition with each other in segmented labour markets. In Canada, the places that receive most immigrants are at the top of the urban hierarchy; the literature on world and global cities provides further arguments as to why immigrants in these cities may experience lower relative earnings. These finding are important because they suggest that the interaction of two urbanization processes-immigration and hi-tech clustering - may contribute to the widening income inequality, which is becoming visible in the largest Canadian cities (Walks and Bourne 2006).

Our findings go further, however, than simply relating immigrants relative earnings in a city to the standing of that city in the urban hierarchy. When we looked at the relative earnings of immigrants in the hi-tech sector in each of the five largest cities, we noted some important variations across these cities. In Toronto, immigrants in the hi-tech sector do worse than immigrants in other sectors, while in Ottawa, immigrants in the hi-tech sector do better than immigrants in other sectors, and about the same as nonimmigrants in the hi-tech sector. This finding points to the limits of urban hierarchy in accounting for the observed variation in the relative earnings of immigrants, and to important differences in these local labour markets. These findings are established within a single sector, and so the observed differences will not easily be explained by differences in industrial structure.

Our data do not allow us to say why the Ottawa labour market was able to deliver better relative outcomes for immigrants in the hi-tech sector in the late 1990s; it is likely that this has something to do with the hi-tech boom in the city at that time, as well as with the role of the Federal Government as an employer and as a local purchaser of products and services. Likewise, we cannot say why the Toronto labour market failed immigrants in the hi-tech sector so badly. Our evidence is consistent with the notion that immigrants in Toronto are on the front lines of some of the most unattractive aspects of the new hi-tech economy, receiving lower wages and being subject to more flexible work arrangements. In other places, especially in Canada's midsized and smaller cities, immigrants receive no earnings or wage penalty; indeed they may receive a small premium for the scarce skills and external connections they bring to work. In summary, these findings are consistent with the notion that immigrants may be inserted in a local labour market in a variety of different ways; understanding how and why this occurs in particular places is a topic for further detailed case study research.

In closing we want to emphasize that our findings are mostly troubling, but also a little hopeful, from a policy perspective. There is probably very little that policy-makers can do about the geographic selectivity of either immigrant settlement patterns or hi-tech clustering. Certainly, the record to date of policies designed to disperse either immigrants or hi-tech activity across the 
urban system gives little grounds for optimism (see Castells and Hall 1994; Walton-Roberts 2005). Canadian cities at the top of the urban hierarchy are likely to continue enjoying both of these sources of growth-and this is surely something that the mayors of Toronto, Vancouver and Montréal will continue to encourage vigorously! These trends will exacerbate the established polarization across the Canadian urban system. What we have argued in this paper is that these same trends will also exacerbate the emerging inequality within Canada's largest cities.

Addressing this latter problem requires three types of intervention, one targeted at immigrants, one targeted at the local labour market, and one concerned with urban policy more generally. In terms of immigrants, these findings add support to what might be regarded as the traditional basket of immigrant settlement supports and policies to promote inclusion (see Reitz 1998)-spending on immigrant settlement services, re-training, internships and mentoring, enhancing efforts to recognize skills and qualifications and support for entrepreneurs. In terms of the local labour market, this research supports efforts by local labour market actors to develop institutions and policies that foster more equal outcomes, such as creating clear entry points with ladders for upward mobility, protections against casualization, and large investments in training and skills. The hopeful message for policy-makers in this paper is that there may be lessons to be learned from some of Canada's largest cities about how to deal with these issues. And third, given that the first two policies may not be enough to reverse the increasing polarization in labour market outcomes in the largest cities, attention must be paid to the wider set of urban policies that support equitable access to housing, transportation and community facilities so that whatever happens in the labour market does not create sociospatial polarization.

Yet, all of these interventions come on the horns of a dilemma: successfully addressing the problem of increasing inequality in labour market outcomes for immigrants will inevitably take resources to the largest cities, with the likely result that we will exacerbate the problem of increasing inequality between the largest cities and other cities in the urban system. We do not pre- tend to have a way out of this dilemma; what we can say is that a geographically informed understanding of how and why relative labour market outcomes vary across the urban system is key to understanding the challenges and possibilities ahead.

\section{Acknowledgements}

The research and analysis are based on data from Statistics Canada, and was supported by SSHRC Initiative on the New Economy (Skills Research Initiative) Research Grant 537-20041003. The opinions expressed do not represent the views of Statistics Canada. Indirect access to the 1991-2001 confidential Census microdata (the 20 percent sample) was provided through the Southwestern Ontario Research Data Center. We want to thank the centre analyst, Dr. Pat Newcombe-Welch, and Statistics Canada employees in Ottawa, especially Susan Brunet and Paul Hartung, for their support and assistance. Thanks also to Reg Bonin for research assistance, and to Dan Boothby, Thitima Songsakul, the anonymous reviewers and TCG editor Roger Hayter for their helpful comments on earlier drafts. All the usual disclaimers apply.

\section{References}

alboim, N., finNie, R., and Meng, R. 2005 'The discounting of immigrants' skills in Canada: evidence and policy recommendations' IRPP Choices 11(2), 1-26

ANISEF, P., SWEET, R., and FRENPONG, G. 2003 Labour Market Outcomes of Immigrant and Racial Minority University Graduates in Canada. CERIS Working Paper No. 23

AVDEMIR, A., and SKUTERUD, M. 2005 'Explaining the deteriorating entry earnings of Canada's immigrant cohorts, 1966-2000' Canadian Journal of Economics 38, 641-672

BAUDER, H. 2003 'Brain Abuse', or the devaluation of immigrant labour in Canada' Antipode 35, 699-717

BENNER, C. 2002 Work in the New Economy (Oxford: Blackwell Press)

BORJAS, G. J. 1994 'The economics of immigration' Journal of Economic Literature 32, 1667-1717

BOUDARBAT, B., LEMIEUX, T., and RIDDELL, w. c. 2003 Recent Trends in Wage Inequality and the Wage Structure in Canada. TARGET Working Paper 6 (Available at: http://www.econ.ubc.ca/ ine/, accessed 5 April 2007)

bourne, L. S., and simmons, J. 2003 'New fault lines? Recent trends in the Canadian urban system and their Implications for planning and public policy' Canadian Journal of Urban Research 12, 22-47

CARD, D. 1990 'The impact of the Mariel Boatlift on the Miami labor market' Industrial and Labor Relations Review $43,245-257$

Castells, M., and hall, P. 1994 Technopoles of the World: The Making of Twenty-First-Century Industrial Complexes (London: Routledge)

CHAPPLE, K., MARKuSEN, A., SHROCK, G., YAMAMOTO, D., and yu, P. 2004 'Gauging metropolitan 'high-tech' and 'i-tech' activity' Economic Development Quarterly 18, 10-29 
CHRISTALLER, w. 1933 (1966) Central Places in Southern Germany, translated by C.W. Baskin (Englewood Cliffs, NJ: PrenticeHall)

COFFEY, w., and SHEARMuR, R. 1997 'The growth and location of highorder services in the Canadian urban system, 1971-1991' Professional Geographer 49, 404-418

CRANFord, C. J., vosKo, L. F., and zUKEWICH, N. 2003 'Precarious employment in the Canadian Labour Market: a statistical portrait' Just Labour 3, 6-22

FERNANDEZ, M. 1998 'Asian Indian Americans in the bay area and the glass ceiling' Sociological Perspective 42, 119149

FERNANDEZ, M., and MORISSETTE, R. 2003 Will They Ever Converge? Earnings of Immigrants and Canadian-Born Workers over the Last Two Decades. Ottawa, Analytical Studies Branch Research Paper 215, Statistics Canada

FRIEDMANN, J., and WOLFF, G. 1982 'World city formation: an agenda for research and action' International Journal of Urban and Regional Research 6, 309-344

GERTLER, M. 2001 'Urban economy and society in Canada: flows of people, capital and Ideas' Isuma 119-130

GERTLER, M., FLORIDA, R., GATES, G., and VINODRAI, T. 2002 Competing on Creativity: placing Ontario's Cities in North American Context. Toronto: A report prepared for the Ontario Ministry of Enterprise, Opportunity and Innovation, and the Institute for Competitiveness and Prosperity

HALL, P. 1966 The World Cities (London: Weidenfeld and Nicolson)

HIEBERT, D. 2000 'Immigration and the changing Canadian city' The Canadian Geographer/Le Géographe canadien 44, 2543

HRSDC. 2003 Knowledge Matters (Ottawa: Human Resources and Skills Development Canada)

hum, D., and SIMPSon, w. 1999 'Wage opportunities for visible minorities in Canada' Canadian Public Policy 25, 379-394

-. 2004 'Economic integration of immigrants to Canada: a short survey' Canadian Journal of Urban Research 13, 4662

ICP. 2003 Investing for Prosperity, 2nd Annual Report of the Task Force on Competitiveness, Productivity and Economic Progress. Toronto: The Institute for Competitiveness and Prosperity

KAUfman, в., and hотснкіsS, J. 2003 The Economics of Labor Markets, Sixth edition (Mason, OH: Thomson South-Western)

LARYEA, S. 1998 The Impact of Foreign-Born Labour on Canadian Wages: A Panel Analysis. RUM Working Paper \#98-06

LEMIEUX, T., and CARD, D. 2001 'Education, earnings, and the "Canadian G.I. Bill" ' Canadian Journal of Economics 34, 313344

LEWIS, E. 2004 How Did the Miami Labor Market Absorb the Mariel Immigrants. Federal Reserve Bank of Philadelphia, Working Paper 04-3

MARTIN, R. L. 2000 'Local labour markets: their nature, performance, and regulation' in The Oxford Handbook of Economic Geography, eds. G. Clark, M. Gertler, and M. Feldman (Oxford: Oxford University Press), 455-476

OtTAVIano, G. I. P., and PERI, G. 2005 Rethinking The Gains From Immigration: Theory and Evidence From the U.S. NBER Working Paper 11672 (Cambridge, MA: National Bureau of Economic Research)

-. 2006 Rethinking the Effects of Immigration on Wages. NBER Working Paper 12497 (Cambridge, MA: National Bureau of Economic Research)
PECK, J. 1996 Work-Place: The Social Regulation of Labor Markets (New York: The Guildford Press)

PENDUKAR, K., and PENDUKAR, R. 2002 'Colour my world: have earnings gaps for Canadian-born ethnic minorities changed over time?' Canadian Public Policy 28, 489-512

PERI, G. 2007 'How immigrants affect California employment and wages' California Counts: Population Trends and Projections $8(3), 1-19$

PICOT, G. 2004 'The deteriorating economic welfare of Canadian immigrants' Canadian Journal of Urban Research 13, 2546

REITZ, J. G. 1998 Warmth of the Welcome: The Social and Economic Causes of Economic Success for Immigrants in Different Nations and Cities (Boulder, CO: Westview Press)

-. 2001 'Immigrant success in the knowledge economy: institutional change and the immigrant experience in Canada, 1970-1995' Journal of Social Issues 57, 579-614

-. 2005 'Tapping immigrants' skills: new directions for Canadian immigration policy in the knowledge economy' IRPP Choices 11(1), 1-18

RIGBY, D. L., and ESSLETZBICHLER, J. 2006 'Technological variety, technological change and a geography of production techniques' Journal of Economic Geography 6, 45-70

RIGBY, D. L., and HAYDAMACK, в. 1998 'Regional trajectories of technological change in Canadian manufacturing' The Canadian Geographer/Le Géographe canadien 42, 2-13

SASSEN, s. 1991 The Global City: New York, London, Tokyo (Princeton, NJ: Princeton University Press)

SAXENIAN, A. 1994 Regional Advantage: Culture and Competition in Silicon Valley and Route 128 (Cambridge, MA: Harvard University Press)

-. 1999 Silicon Valley's New Immigrant Entrepreneurs (San Francisco, CA: Public Policy Institute of California)

-. 2006 The New Argonauts: Regional Advantage in a Global Economy (Cambridge, MA: Harvard University Press)

SCHAAFSMA, J., and SWEETMAN, A. 2001 'Immigrant earnings: age at immigration matters' Canadian Journal of Economics 34, 1066-1099

SHEARMUR, R., and DOLOREUX, D. 2007 Urban Hierarchy or Local Milieu? High-order Producer Service and (or) KnowledgeIntensive Business Service Location in Canada, 1991-2001. Paper presented to the Innovation Systems Research Network (Available at: http://www.utoronto.ca/isrn/ publications/WorkingPapers/Working07/Doloreux_Shearmur 07_KIBSLocation.pdf, accessed 20 August 2007)

SWEETMAN, A. 2004 'Introduction to economic and urban issues in Canadian immigration policy' Canadian Journal of Urban Research 13, 1-25

TANG, J. 1993 'The career attainment of Caucasian and Asian engineers' Sociological Quarterly 34, 467-496

walks, R. A., and BOURNE, L. s. 2006 'Ghettos in Canada's cities? Racial segregation, ethnic enclaves and poverty concentration in Canadian urban areas' The Canadian Geographer/Le Géographe canadien 50, 273-297

WALTON-ROBERTS, M. 2005 'Regional immigration and dispersal: lessons from small- and medium-sized urban centres in British Columbia' Canadian Ethnic Studies 37, 12-34

WARMAN, C. R., and WORSWICK, c. 2004 'Immigrant earnings performance in Canadian cities: 1981 through 2001' Canadian Journal of Urban Research 13, 62-85

wolfe, D. ed. 2003 Clusters Old and New: The Transition to a Knowledge Economy in Canada's Regions (Montréal and Kingston: Queens University Press) 